CASE REPORT

\title{
Pulmonary Artery Bullet Emboli: To Retrieve or Not? A Contemporary Reassessment
}

\author{
Stephanie R Goldberg ${ }^{1}$, Anthony Cassano ${ }^{2}$, Rao R Ivatury ${ }^{3}$
}

\begin{abstract}
Aim: We present two patients with bullet emboli to the pulmonary artery and discuss their management based on a review of the literature. Background: Bullet emboli to the pulmonary arteries from abdominal gunshot wounds are rare. It is unclear whether these bullets should be removed in stable, asymptomatic patients.

Case description: We discuss the management of two cases of bullet emboli to the pulmonary arteries and the associated morbidity and mortality, based on a thorough review of the relevant literature.

Conclusion: We recommend elective removal of the asymptomatic bullet to the pulmonary artery once patients have been appropriately resuscitated or on a close follow-up of the compliant patient.

Clinical significance: The complex management of these patients necessitates an individualized management with a collaborative approach between cardiothoracic and trauma surgeons.
\end{abstract}

Keywords: Bullet, Chest, Embolus, Penetrating trauma, Pulmonary artery.

Panamerican Journal of Trauma, Critical Care \& Emergency Surgery (2019): 10.5005/jp-journals-10030-1243

\section{RESUMO}

Objetivo: Apresentamos dois pacientes com êmbolo de projétil de arma de fogo (bala) na artéria pulmonar e discutimos seu manejo com base em uma revisão da literatura.

Antecedentes: Os êmbolos de bala nas artérias pulmonares decorrentes de ferimentos por arma de fogo abdominais são raros. Não está claro se essas balas devem ser removidas em pacientes estáveis e assintomáticos.

Descrição do caso: Discutimos o tratamento de dois casos de êmbolos de projétil de arma de fogo (bala) nas artérias pulmonares e a morbimortalidade associada, com base em uma revisão minuciosa da literatura relevante.

Conclusão: Recomendamos a remoção eletiva do projétil de arma de fogo assintomático na artéria pulmonar, uma vez que os pacientes tenham sido adequadamente ressuscitados ou após acompanhamento de perto destes pacientes.

Significado clínico: O manejo complexo desses pacientes requer planejamento e condução individualizados, com uma abordagem colaborativa entre os cirurgiões de trauma e os cardiotorácicos.

Palabras clave: Artéria Pulmonar, Bala, Embolia, Projétil de Arma de Fogo, Tórax, Trauma penetrante.

\section{BACKGROUND}

Bullet emboli to the pulmonary arteries resulting from distant gunshot wounds are exceedingly rare. It remains unclear if asymptomatic patients should preemptively undergo bullet removal. We present two patients with bullet emboli to the pulmonary artery and review the reported cases in the literature to optimize their management.

\section{CASE 1}

A 40-year-old male was shot from close range to his extremities and abdomen. He was alert and oriented with a blood pressure of $80 / 40 \mathrm{~mm} \mathrm{Hg}$ with a heart rate of 130's in the field. At the trauma center, he had a blood pressure of $140 / 80 \mathrm{~mm} \mathrm{Hg}$ and a pulse rate of 123 beats per minute. He was noted to have a gunshot wound to the epigastrium and a through-and-through injury to both the left forearm and the thigh. Lateral and upright chest X-rays demonstrated a foreign body, consistent with a bullet, posterior to the heart. At laparotomy, he was noted to have $>2 \mathrm{~L}$ hemoperitoneum with injuries to the transverse colon, jejunum, third portion of the duodenum, and a non-expanding zone-I retroperitoneal hematoma. Intraoperatively, he was hypothermic
${ }^{1}$ Department of Surgery, Division of Trauma and Emergency General Surgery, Virginia Commonwealth University, Richmond, Virginia, USA

2,3 Department of Surgery, Virginia Commonwealth University, Richmond, Virginia, USA

Corresponding Author: Stephanie R Goldberg, Department of Surgery, Division of Trauma and Emergency General Surgery, Virginia Commonwealth University, Richmond, Virginia, USA, Phone: +1-804827-2409, e-mail: sgoldberg@mcvh-vcu.edu

How to cite this article: Goldberg SR, Cassano A, et al. Pulmonary Artery Bullet Emboli: To Retrieve or Not? A Contemporary Reassessment. Panam J Trauma Crit Care Emerg Surg 2019;8(2):96-101.

Source of support: Nil

Conflict of interest: None

to $34^{\circ}$ and acidotic to a $\mathrm{pH}$ of 7.22 . Upon medial visceral rotation, a through-and-through injury to the inferior vena cava below the level of the renal veins was identified and repaired primarily. A damage control laparotomy was performed with the rapid repair of the colon, resection of the jejunu $m$, and repair of the third portion of the duodenum. The abdomen was packed, leaving the bowel in discontinuity. The abdomen was left open. He was returned to the 


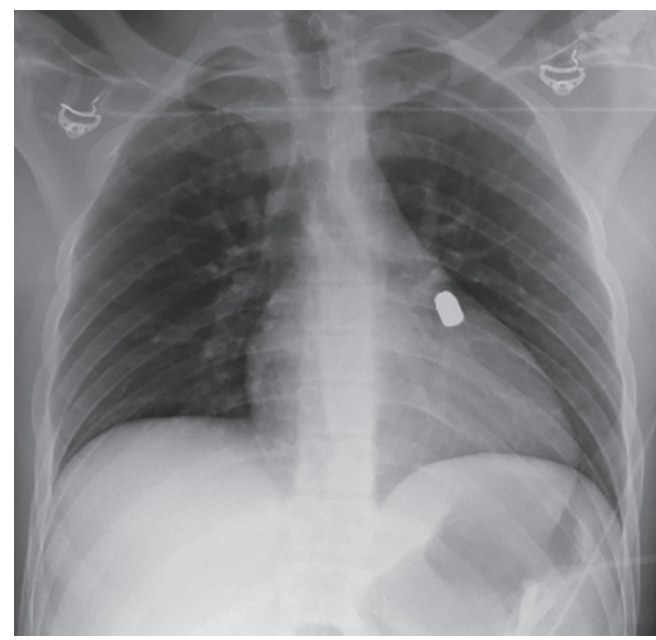

Fig. 1: AP and lateral chest X-ray showing bullet posterior to heart

operating room after resuscitation. The segments of the jejunum were anastomosed and the colon was re-anastomosed as a colocolostomy. The patient did well postoperatively until day 22, when he became febrile with an elevated white blood cell count of $22 \mathrm{~K}$. He had scattered rales and rhonchi at the left base. Computerized tomography (CT) scan of the chest and the abdomen were obtained and showed evidence of a left lower lobe pneumonitis, a foreign body (bullet) in the left lower lobe and an insignificant abdominal $\mathrm{CT}$. Even though a bronchoscopy and brochoalveolar lavage were negative for organisms, he was started on antibiotics. He became increasingly septic, however, and subsequently developed septic shock. A thoracotomy and lower lobectomy were emergently scheduled, but he expired from sepsis before he could be taken to the operating room. An autopsy confirmed a necrotizing pneumonia of the left lower lobe adjacent to the retained bullet.

\section{CASE 2}

A 21-year-old male sustained a gunshot wound to the right upper quadrant. Prior to abdominal exploration, anterior-posterior and lateral chest X-rays demonstrated a single bullet posterior to the heart with no evidence of pneumothorax or hemothorax (Fig. 1). A focused assessment with sonography in trauma (FAST) exam was negative for the pericardial fluid. Abdomen/pelvis CT showed a complex liver

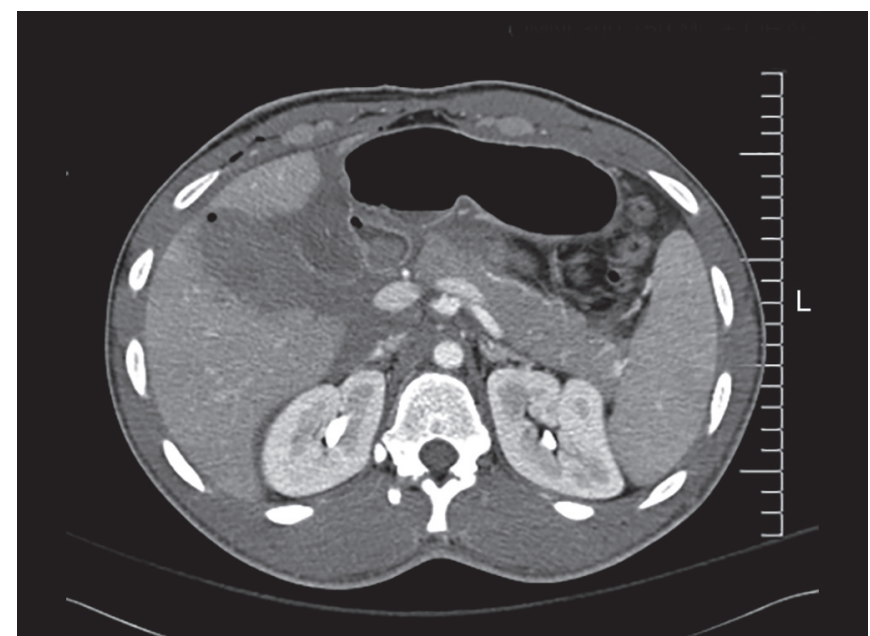

Fig. 3: Chest CT scan image demonstrating bullet lodged in pulmonary artery

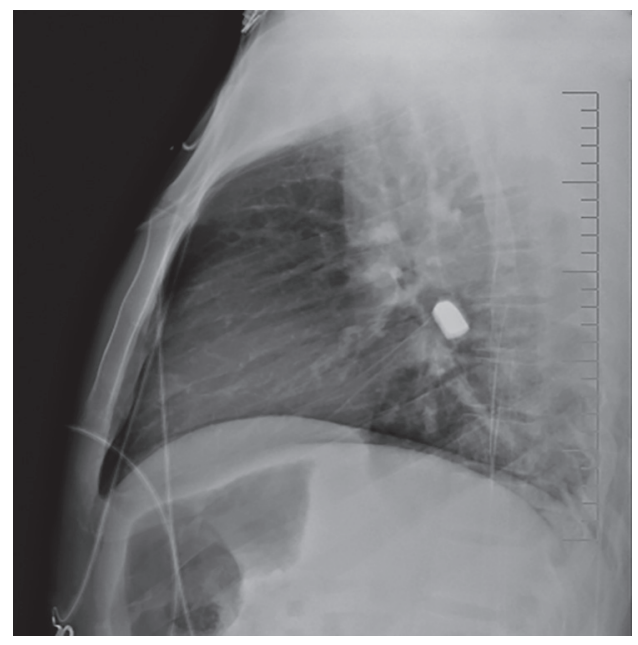

Fig. 2: Abdomen/pelvis CT scan image demonstrating liver injury and fluid surrounding duodenum

injury with fluid surrounding the duodenum (Fig. 2). Chest CT scan demonstrated a single bullet lodged in the left pulmonary artery (Fig. 3). At the time of laparotomy, he was noted to have a complex liver laceration, duodenal injury, and laceration of the anterior wall of the inferior vena cava at the level of the right renal vein. These injuries were managed with primary repair. Subxiphoid pericardial window performed was negative for blood. A missile embolus was diagnosed but was left in situ. He improved postoperatively and was discharged home without bullet removal. An echocardiogram (ECHO) was planned for 6 months later to evaluate his right heart function. Seven weeks later, the patient presented with chest pain and shortness of breath with oxygen saturations of $97 \%$ on $100 \%$ oxygen non-rebreather. A chest CT scan showed evidence of a large left pneumothorax with a concern for broncho-pleural fistula and empyema. Following chest tube placement, he was taken emergently to the operating room for exploration. There was $300 \mathrm{cc}$ of purulent material in the chest and over $50 \%$ of the left lower lung was necrotic. A left lobectomy was performed through a thoracotomy incision. Pathology was consistent with subpleural hematoma and infarction with adjacent acute pneumonia and acute fibrinous pleuritis. Microbiology was positive for Streptococcus milleri and mixed anaerobic bacteria. He completed a 4-week course of Zosyn which was converted to Augmentin for an additional 2 weeks of coverage. He did well on follow-up.

\section{Discussion}

The optimal management in arterial missile emboli is agreed upon uniformly. It is, however, not as clear on the venous side, because of the need for a major procedure of thoracotomy and the "presumed" absence of clear-cut threat for complications. "Presumed" because a careful review of the reported experience raises some questions whether non-interventional observation is always a good option in pulmonary missile emboli. Further, recent innovations in minimally invasive surgical techniques and interventional radiological and hybrid procedures provide a less severe alternative option to thoracotomy.

To reevaluate the management in this era of technologic advances, we have rereviewed the existing literature, adding two cases of pulmonary artery bullet emboli. Literature search revealed three significant reports of the phenomenon: Shannon et al. (126 cases, 1929-1987) ${ }^{1}$ and Miller et al. (45 cases, 1987-2011). ${ }^{2}$ We found an additional 17 cases to date including the two reported here. These are summarized in Tables 1 and $2 .{ }^{3-55}$ 
Table 1:Venous missile embolism—-iterature summary 1900-1929; 1930-1987, Reproduced wirh permission, Shannon et al. ${ }^{1}$

\begin{tabular}{|c|c|c|c|c|}
\hline \multicolumn{2}{|c|}{ Origin } & \multirow[b]{2}{*}{ Final destination } & \multicolumn{2}{|c|}{ Dale of report } \\
\hline Below diaphragm & Above diaphragm & & 1900-1929 & 1930-1987 \\
\hline \multirow[t]{4}{*}{23} & 4 & Right heart & 13 & 48 \\
\hline & & Missile removed & $1(8 \%)$ & $32(67 \%)$ \\
\hline & & Embolus morbidity & 0 & $3(6 \%)$ \\
\hline & & Embolus mortality & $5(62 \%)$ & $1(4 \%)$ \\
\hline \multirow[t]{4}{*}{16} & 13 & Pulmonary artery & 7 & 38 \\
\hline & & Missile removed & 0 & $21(55 \%)$ \\
\hline & & Embolus morbidity & 0 & $7(18 \%)$ \\
\hline & & Embolus mortality & $5(71 \%)$ & $3(8 \%)$ \\
\hline \multirow[t]{4}{*}{7} & 8 & Peripheral/central vein & 3 & 12 \\
\hline & & Missile removed & $2(66 \%)$ & $7(58 \%)$ \\
\hline & & Embolus morbidity & 0 & $2(17 \%)$ \\
\hline & & Embolus mortality & 0 & 0 \\
\hline \multirow[t]{4}{*}{5} & 0 & Paradoxic systemic artery & 1 & 4 \\
\hline & & Missile removed & 0 & $4(100 \%)$ \\
\hline & & Embolus morbidity & 0 & $4(50 \%)$ \\
\hline & & Embolus mortality & $1(100 \%)$ & 0 \\
\hline \multirow[t]{4}{*}{51} & 25 & Total & 24 & 102 \\
\hline & & Missile removed & $4(17 \%)$ & $64(64 \%)$ \\
\hline & & Embolus morbidity & 0 & $14(14 \%)$ \\
\hline & & Embolus mortality & $11(46 \%)$ & $4(4 \%)$ \\
\hline
\end{tabular}

Table 2: Reported cases of venous embolism (1987-2016)

\begin{tabular}{|c|c|c|c|c|}
\hline S. no. & Author (year) & Site of primary injury & Visceral injuries & Treatment \\
\hline 1 & Rehm et al. (1988) & Chest & Rt hepatic vein & Endovascular \\
\hline 2 & Patel et al. (1989) & Abdomen & PA 1 & Observation \\
\hline 3 & Patel et al. (1989) & Abdomen & PA 2 & Obeservation \\
\hline 4 & Patel et al. (1989) & Abdomen & Right atrium & Open removal \\
\hline 5 & Schmelzer et al. (1989) & Chest & L SC vein popliteal vein & Observed \\
\hline 6 & Vázquez-Valdé s et al. (1989) & Chest & PA PL & Thoracotomy \\
\hline 7 & Michelassi et al. (1990) & Abdomen & Right atrium & $\begin{array}{l}\text { Sternotomy/cardiopulmonary } \\
\text { (CP) bypass }\end{array}$ \\
\hline 8 & John and Edmondson (1991) & Abdomen & Pulmonary artery (PA) & Unknown \\
\hline 9 & Van Arsdell et al. (1991) & Head & Right ventricle & Open \\
\hline 10 & Colquhoun et al. (1991) & Neck & Right ventricle & Sternotomy/CP bypass \\
\hline 11 & Colquhoun et al. (1991) & Inguinal & Rt atrium & Sternotomy/CP bypass \\
\hline 12 & Kortbeek et al. (1992) & Abdomen & PA & Observation \\
\hline 13 & Martí et al. (1991) & Chest & $\begin{array}{l}\text { Superior vena cava (SVC) right } \\
\text { ventricle }\end{array}$ & Unknown \\
\hline 14 & Nazir et al. (1992) & Chest & Right ventricle & Open/failed endovascular \\
\hline 15 & Nagy et al. (1994) & Lower extremity & Iliac right ventricle & Observation \\
\hline 16 & O’Neill et al. (1996) & Abdomen & RV Inferior vena cava (IVC) RA & Transjugular \\
\hline 17 & Panichabhongse et al. (1996) & Abdomen & Right (Rt) PA & Observation \\
\hline 18 & Schurr et al. ${ }^{45}(1996)$ & $\begin{array}{l}\text { L external iliac vein } \\
\text { PFO open, Common } \\
\text { iliac artery L }\end{array}$ & $\begin{array}{l}\text { Ex Lap, open removal w/ } \\
\text { arteriotomy }\end{array}$ & \\
\hline 19 & Headrick et al. (1997) & Abdomen & IVC right ventricle & Sternotomy/CP bypass \\
\hline 20 & Lodder (1997) & Lower extremity & PA & Observation \\
\hline 21 & Schöpf et al. (1998) & Head & PA & Unknown \\
\hline 22 & Kaushik and Mandal (1999) & Lower extremity & Iliac vein RA & Endovascular \\
\hline 23 & Pollak et al. (1999) & Inguinal & Right atrium & Observation \\
\hline \multirow[t]{2}{*}{24} & Obermeyer et al. (2000) & Buttock & Right ventricle & Observation \\
\hline & & & & \\
\hline 98 & \multicolumn{4}{|c|}{ Panamerican Journal of Trauma, Critical Care \& Emergency Surgery, Volume 8 Issue 2 (May-August 2019) } \\
\hline
\end{tabular}




\begin{tabular}{|c|c|c|c|c|}
\hline S. no. & Author (year) & Site of primary injury & Visceral injuries & Treatment \\
\hline 25 & Luison and Inculet (2001) & Chest & R Brachiocephalic Vein PA & Observation \\
\hline 26 & Best (2001) & Buttock & Right heart & $\begin{array}{l}\text { Transfemoral extraction } \\
\text { endovascular (EV) }\end{array}$ \\
\hline 27 & Wales et al. (2001) & Chest & Right ventricle & Sternotomy $w / C P$ bypass \\
\hline \multirow[t]{2}{*}{28} & Kalimi et al. (2002) & Buttock & Right ventricle & Failed retrieval, observation \\
\hline & & & & And sternotomy/CP bypass \\
\hline 29 & Lucena and Romero (2002) & Chest & External iliac vein & Autopsy \\
\hline 30 & Berkan and Gu nay (2002) & Inguinal & Right ventricle & Observation \\
\hline 31 & Corbett et al. (2003) & Inguinal/Flank & IVC PFO common femoral artery & Open \\
\hline 32 & Bertoldo et al. (2004) & Chest & SVC iliac IVC & Thoracotomy \\
\hline 33 & Bett and Walters (2004) & Neck & Right ventricle & Observation/pacemaker \\
\hline 34 & Demirkilic et al. (2004) & Lower extremity & $\mathrm{PA}$ & Sternotomy/CP bypass \\
\hline 35 & Hughes and Vender (2006) & Head & PA & Observation \\
\hline 36 & Agarwal et al. (2007) & Neck & $\mathrm{PA}$ & Thoracotomy \\
\hline 37 & Bining et al. (2007) & Flank/lower extremity & Right ventricle & Sternotomy \\
\hline 38 & Breeding et al. (2007) & Neck & Right atrium & Sternotomy/endovascular \\
\hline 39 & Chen et al. (2007) & Flank & PA & Endovascular \\
\hline 40 & Dulić et al. (2007) & Lower extremity & PA & Observation \\
\hline 41 & Ettinger et al. (2007) & Chest & Right heart & Sternotomy/CP bypass \\
\hline 42 & Bors et al. (2008) & Chest & $L B C$ vein right ventricle & Open removal/CP bypass \\
\hline 43 & Engelgardt et al. (2008) & Head & SVC IVC femoral vein & Autopsy \\
\hline 44 & Raikar et al. (2009) & Buttock & Hepatic vein & Endovascular \\
\hline 45 & Jo et al. (2010) & Head & PA & Thoracotomy, embolectomy \\
\hline 46 & Miller et al. (2011) & Left chest & Suprahepatic cava & Snare, trans Fem venous $(\mathrm{Vn})$ \\
\hline 47 & Miller et al. (2011) & Rt chest & Rt ventricle & Snare, trans Fem \\
\hline 48 & Miller et al. (2011) & Transpelvic & IVC, colon, Rt atrial appendage & $\begin{array}{l}\text { Transluminal snare right } \\
\text { internal jugular (Rt IJ) }\end{array}$ \\
\hline 49 & Miller et al. (2011) & Abdomen & Enteric, IVC, Rt ventricle & $\begin{array}{l}\text { Transluminal endosnare thr } \\
\text { cavotomy }\end{array}$ \\
\hline 50 & Nolan et al. (2012) & Abdomen & IVC, retrohep cava to iliac & Snared, removed by femoral Vn \\
\hline 51 & Gustavo (2013) & Right buttock & Rt iliac vein to Rt PA & $\begin{array}{l}\text { Endo snaring unsuccessful. } \\
\text { Observed }\end{array}$ \\
\hline 52 & Wilkins (2014) & Chest & L Pulmonary artery & post lat thoracotomy \\
\hline 53 & Duke et al. (2015) & $\mathrm{BB}$ to right globe & Trans (Tr) sinus right heart, PA & Left alone \\
\hline 54 & Lu et al. (2015) & Abdomen, iliac, & Rt ventricle & Ensnare, later sternotomy \\
\hline 55 & McTyre et al. (2015) & Abdomen & PA & None, OK \\
\hline 56 & Eicevarra (2015) & Thighs & PA & Failed snaring. thoracotomy, \\
\hline 57 & Doud et al. (2015) & Abdomen & Bowel, ureter rt ventric septum & Sternotomy \\
\hline 58 & Pavlekić (2016) & Thigh, neck & IJ, ext iliac & Autopsy \\
\hline 59 & Imbert (2016) & Chest & Right ventricle & Observation. Embolized twice \\
\hline 60 & Wilkins (2016) & Chest & $\begin{array}{l}\text { Right middle lobe of the lung, the } \\
\text { right hemidiaphragm, segments } \\
4 A \text { and } 1 \text { of the liver, and the } \\
\text { intrahepatic IVC }\end{array}$ & Thoracotomy \\
\hline 61 & Goldberg (2016) & Abdomen & Colon, IVC & Autopsy \\
\hline 62 & Goldberg (2016) & Abdomen & Duodenum, colon, IVC & Thoracotomy \\
\hline
\end{tabular}

After: Appendix ${ }^{2}$

Bullet embolism is a rare, potentially life-threatening complication of penetrating missile trauma. It occurs when a smallcaliber bullet enters the blood stream ${ }^{1,2}$ with enough velocity to penetrate one wall of a vessel. It loses momentum once inside the lumen, as might happen with BBs, 0.22 caliber bullets, airgun pellets, or shotguns ammunition. The free-floating foreign body may then be carried by the bloodstream or if free within a body cavity, by gravity or a change in body position. ${ }^{1-5}$ Migrating venous bullets lodge in the right ventricle more often than the pulmonary arterial tree since they tend to be trapped beneath the tricuspid valve or the chordae tendinae. Arterial missile emboli are carried downstream in the arterial tree after the bullet is lodged in the left side of the heart or the major arterial branches. Paradoxical emboli cross over from the venous system to the arterial system, either through a large 
A-V fistula or, as is more usual, through a patent foramen ovale., ${ }^{1,2,17}$ Rarely, a double play is to blame: Corbett $^{30}$ described a case where a bullet to the flank and groin embolized to the common femoral artery, via retrohepatic cava, right heart, patent foramen ovale, and then the arterial circulation.

The first reported venous embolus was by Davis in 1834 as a case of a wooden fragment embolizing from the venous circulation to the right ventricle in a 10 -year-old boy. ${ }^{52}$ Bullet embolism should be suspected by an odd number of missile wounds or a bullet lies outside the established trajectory, or suggested by changing position of a missile on radiographs. In the majority of cases, the initial wounding site is the chest or the abdomen. Rarely the head and the neck or extremity penetration was the primary site of entry. The emboli may be discovered both at the time of presentation and as late as 59 years after the initial injury. ${ }^{50}$

There is no consensus on whether aggressive retrieval is necessary for asymptomatic patients. ${ }^{1,2,7,11,14,18,45-51}$ Reasons for removal of bullet emboli to the pulmonary artery include complications of bullet erosion, local hemorrhage, and pulmonary infarction with the risk of infection. ${ }^{1-5}$ Studies supporting the removal of venous bullet emboli stem from data showing a $13 \%$ complication rate from retained right heart missles often month to years following the initial injury. ${ }^{1,2}$ Similarly, in a review of 102 cases reported since 1930, Shannon et al. ${ }^{1}$ demonstrated a retrieval rate of $64 \%$ and an embolus-related mortality of $4 \%$, Table 1 . These authors advocated bullet extraction given the high morbidity and considerable mortality rate. In the reported cases since 1987, more than $50 \%$ of emboli underwent intervention. ${ }^{2}$ The majority of them were extracted through open operation (24/61), endovascular (11/45), or hybrid open/endovascular (2/61) approaches. Four cases were at autopsy. In three cases, the management was unclear. Five open procedures were performed following failed endovascular retrieval (Table 2).

Eighteen of the 61 cases were managed by careful observation, with most of these restings within the pulmonary artery in asymptomatic patients. In a couple of patients, initial attempts at endovascular attempts failed and the patients were observed without further treatment. Conservative management was advocated by Kortbeek et al., ${ }^{11}$ who in 1992 reviewed 32 cases of pulmonary artery bullet emboli that were observed without complication. Observation is apparently appropriate when bullets lodged in the pulmonary tree do not cause a pulmonary infarction, pulmonary abscess, or erosion in the bronchus or when the emboli were detected late after the primary event. ${ }^{1}$

More than $50 \%(10 / 16)$ of the interventions for bullet emboli reported since 2007 underwent either an endovascular or a hybrid retrieval. The series of Miller et al. ${ }^{2}$ reported in 2011 documented a $100 \%$ endovascular retrieval in the reported four cases. A recent report emphasized the use of endovascular retrieval of bullet embolism. ${ }^{45}$ These techniques have reduced the morbidity and the mortality of intracardiac bullet retrieval, and have favored prophylactic retrieval of bullet emboli to prevent complications. Endovascular bullet retrieval still requires surgical bullet extraction through arteriotomy and venotomy. ${ }^{1,2}$ Whether the advent of newer techniques or the decreased morbidity from avoiding a thoracotomy should influence the decision to proceed with bullet retrieval in the hemodynamically stable patient remains unknown. The question becomes even more pertinent for embolized bullets that became contaminated by trans-enteric migration.

Traditional surgical dogma would suggest that bullet penetration of the gastrointestinal tract and subsequent embolization would present the chance for infection around the embolization site, perhaps augmented by adjacent tissue necrosis. This may explain the not-too-infrequent finding of associated pulmonary infarction. It is conceivable that bullets undergoing trans-colonic penetration with higher bacterial counts may lead to higher associated infection rates around these embolized bullets than those without associated enteric penetration. Shannon et al. ${ }^{1}$ strongly support this concept as a reason to extract such embolized bullets. Similarly, whether the source of infection arose from a bullet contaminated with enteric contents bathed in the blood or from the infarcted lung tissue remains unknown. Both patients presented in this series, however, developed bullet-associated lung infection and sepsis after their migration through the duodenum and the colon. It is also sobering to realize that this resulted in a septic death of one of our two cases.

The cases reported in the literature also provide fascinating operative facts. In four of nine patients who underwent thoracotomy for retrieval, the missile was dislodged during manipulation and a second thoracotomy was required in three of them. ${ }^{56}$ In one recent report of a bullet embolus to the inferior branch of the pulmonary artery, $^{52}$ interventional radiology was unsuccessful in attempts at endovascular bullet retrieval necessitating operative retrieval through a left posterolateral thoracotomy. During dissection and mobilization of the left pulmonary artery, the bullet became dislodged and was no longer palpable. Intraoperative chest radiograph revealed that the bullet had traveled into the right PA! The left thoracotomy incision was closed with a towel clip closure and the patient placed the right side up in the decubitus position. Vigorous percussion of the right chest relocated the missile to the left side as confirmed by a chest $\mathrm{X}$-ray. The bullet was extracted through a pulmonary arteriotomy. The authors commented on the intraoperative use of an inflated Swan-Ganz catheter to prevent bullet migration during patient positioning and operative manipulation. ${ }^{52}$

\section{Conclusion}

Based on a review of the reported experience on pulmonary missile emboli, we recommend elective removal even in the asymptomatic patient when the bullets are potentially contaminated by transcolonic migration.

\section{Clinical Significance}

The complex management of these patients necessitates a collaborative approach between cardiothoracic and trauma surgeons to decrease morbidity and mortality among this very rare group of patients.

\section{References}

1. Shannon $\mathrm{FL}, \mathrm{McC}$ roskey $\mathrm{BL}$, et al. Venous bullet embolism: rationale for mandatory extraction. J Trauma 1987 Oct;27(10):1118-1122. DOI: 10.1097/00005373-198710000-00004.

2. Miller KR, Benns MV, et al. The Evolving Management of Venous Bullet Emboli: A Case Series and Literature Review. Injury Int J Care Injured 2011;42:441-446. DOI: 10.1016/j.injury.2010.08.006.

3. Rehm C, Alspaugh JP, et al. Bullet embolus to the right hepatic vein after agunshot wound to the heart and its percutaneous retrieval. J Trauma 1988;28(5):719-720. DOI: 10.1097/00005373-19880500000035.

4. Patel KR, Cortes LE, et al. Bullet embolism. J Cardiovasc Surg (Torino) 1989;30(4):584-590.

5. Schmelzer V, Mendez-Picon G, et al. Case report: transthoracic retrograde venous bullet embolization. J Trauma 1989;29(4):525-527. DOI: 10.1097/00005373-198904000-00021.

6. Vázquez-Valdés E, Centeno-Olguín V, et al. Embolism caused by a bullet. Report of a case and review of the literature. Rev Invest Clin 1989;41(1):57-62. 
7. Michelassi F, Pietrabissa A, et al. Bullet emboli to the systemic and venous circulation. Surgery 1990;107(3):239-245.

8. John LC, Edmondson SJ. Bullet pulmonary embolus and the role of surgery. Thorac Cardiovasc Surg 1991 Dec;39(6):386-388. DOI: 10.1055/s-2007-1020007.

9. Van Arsdell GS, Razzouk AJ, et al. Bullet fragment venous embolus to the heart: case report. J Trauma 1991;31(1):137-139. DOI: 10.1097/00005373-199101000-00027.

10. Colquhoun IW, Jamieson MP, et al. Venous bullet embolism: a complication of airgun pellet injuries. Scott Med J 1991;36(1):16-17. DOI: 10.1177/003693309103600107.

11. Kortbeek JB, Clark JA, et al. Conservative management of a pulmonary artery bullet embolism: case report and review of the literature. J Trauma 1992;33(6):906-908. DOI: 10.1097/00005373-19921200000020.

12. Martí V, Augé JM, et al. Bullet embolism of the right ventricle following gunshot wound. Rev Esp Cardiol 1992;45(7):489-491.

13. Nazir Z, Esufali ST, et al. Venous bullet embolism: a case report and review of the literature. Injury 1992;23(8):561-563. DOI: 10.1016/00201383(92)90163-M.

14. Nagy KK, Massad M, et al. Missile embolization revisited: a rationale for selective management. Am Surg 1994;60(12):975-979.

15. O'Neill PJ, Feldman DR, et al. Trans-jugular extraction of bullet embolus to the heart. Mil Med 1996;161(6):360-361. DOI: 10.1093/ milmed/161.6.360.

16. Panichabhongse V, Kasantikul V, et al. Bullet embolus to the right pulmonary artery after abdominal gunshot wound with "piggyback bullet". J Med Asso Thai 1996 Oct;79(10):676-679.

17. Schurr M, McCord S, et al. Paradoxical bullet embolism: case report and literature review. J Trauma 1996;40(6):1034-1036. DOI: 10.1097/00005373-199606000-00034.

18. Headrick Jr JR, Mugosa M, et al. Venous bullet embolism: controversies in management. Tenn Med 1997;90(3):103-105.

19. Lodder JV. Venous bullet embolism. a case report. S Afr J Surg 1997;35(2):94-97.

20. Schöpf $R$, Lungenschmid $D$, et al. Bullet embolism in the right pulmonary artery. Aktuelle Radiol 1998;8(4):203-204.

21. Kaushik VS, Mandal AK. Non-surgical retrieval of a bullet embolus from the right heart. Catheter Cardiovasc Interv 1999;47(1):55-57. DOI: 10.1002/(SICI)1522-726X(199905)47:1<55::AID-CCD12>3.0.CO;2-H.

22. Pollak $S$, Ropohl $D$, et al. Pellet embolization to the right atrium following double shotgun injury. Forensic Sci Int 1999;99(1):61-69. DOI: 10.1016/S0379-0738(98)00177-7.

23. Obermeyer RJ, Fecher A, et al. Embolization of bullet to the right ventricle. Am J Surg 2000;179(3):189. DOI: 10.1016/S00029610(00)00290-7.

24. Luison F, Inculet RI. Soft-tissue images. Bullet embolism. Can J Surg 2001;44(4):258.

25. Best IM. Transfemoral extraction of an intracardiac bullet embolus. Am Surg 2001;67(4):361-363.

26. Wales $L$, Jenkins $D P$, et al. Delayed presentation of right ventricular bullet embolus. Ann Thorac Surg 2001;72(2):619-620. DOI: 10.1016/ S0003-4975(00)02580-7.

27. Kalimi R, Angus LD, et al. Bullet embolization from the left internal iliac vein to the right ventricle. J Trauma 2002;52(4):772-774. DOI: 10.1097/00005373-200204000-00030.

28. Lucena JS, Romero C. Retrograde transthoracic venous bullet embolism. report of a case following a single gunshot with multiple wounds in the left arm and chest. Forensic Sci Int 2002;125(2-3): 269-272. DOI: 10.1016/S0379-0738(02)00010-5.

29. Berkan O, Günay I. An unusual case of birdshot embolism. Circ J 2002;66(7):707-708. DOI: 10.1253/circj.66.707.

30. Corbett H, Paulsen EK, et al. Paradoxical bullet embolus from the vena cava: a case report. J Trauma 2003;55(5):979-981. DOI: 10.1097/01. TA.0000028835.94166.68.

31. Bertoldo U, Enrichens F, et al. Retrograde venous bullet embolism: a rare occurrence-case report and literature review. J Trauma 2004;57(1):187-192. DOI: 10.1097/01.TA.0000135490.10227.5C.
32. Bett N, Walters L. Delayed presentation of right ventricular bullet embolus. Heart 2004;90(11):1298. DOI: 10.1136/hrt.2004.037804.

33. Demirkilic U, Yilmaz AT, et al. Bullet embolism to the pulmonary artery. Interact Cardiovasc Thorac Surg 2004;3(2):356-358. DOI: 10.1016/ j.icvts.2004.02.002.

34. Hughes BD, Vender JR. Delayed lead pulmonary emboli after a gunshot wound to the head. Case report. J Neurosurg 2006;105(3 Suppl): 233-234.

35. Agarwal SK, Singh A, et al. Wandering bullet embolizing to the pulmonary artery: a case report. Asian Cardiovasc Thorac Ann 2007;15(2):154-156. DOI: 10.1177/021849230701500215.

36. Bining $\mathrm{HJ}$, Artho GP, et al. Venous bullet embolism to the right ventricle. Br J Radiol 2007;80(960):e296-e298. DOI: 10.1259/ bjr/64277826.

37. Breeding JM, Smith RS, et al. Bullet embolus to the heart after gunshot wound to the neck: a case report. Am Surg 2007;73(12):1245-1246.

38. Chen JJ, Mirvis SE, et al. MDCT diagnosis and endovascular management of bullet embolization to the heart. Emerg Radiol 2007;14(2):127-130. DOI: 10.1007/s10140-007-0592-2.

39. Dulić G, Candrlić K, et al. Pulmonary embolism caused by a migrated gunshot projectile. Coll Antropol 2007;31(2):629-631.

40. Ettinger J, Hohlenwerger C, et al. Cardiac bullet embolus after thoracic vena cava penetrating injury causing tricuspid valve insufficiency. Int J Surg 2007;5(1):66-68. DOI: 10.1016/j.ijsu.2006.04.008.

41. Bors V, Aubert S, et al. Bullet embolization from the left brachiocephalic vein to the right ventricle. J Card Surg 2008;23(2):176-177. DOI: 10.1111/j.1540-8191.2007.00515.x.

42. Engelgardt P, Wolska E, et al. Bullet embolism. Arch Med Sadowej Kryminol 2008;58(4):224-227.

43. Raikar SS, Jureidini SB, et al. The fantastic journey of a bullet: out with a snare. Pediatr Cardiol 2009;31(1):108-110.

44. Jo C, Steed MB, et al. Bullet embolus to the pulmonary artery after gunshot wound to the face: case report and review of literature. J Oral Maxillofac Surg 2010;68(3):504-507. DOI: 10.1016/j.joms.2009.04.052.

45. Nolan T, Phan H, et al. Bullet embolization: multidisciplinary approach by interventional radiology and surgery. Semin Intervent Radiol 2012 Sep;29(3):192-196. DOI: 10.1055/s-0032-1326928.

46. Mctyre E, McGill L, et al. Missile pulmonary embolus secondary to abdominal gunshot wound. RCR 2012;7:2-3. DOI: 10.2484/rcr.v7i3.709.

47. Fernandez-Ranvier GG, Mehta P, et al. Pulmonary artery bullet embolism-Case report and review. Int J Surg Case Rep 2013;4(5): 521-523. DOI: 10.1016/j.ijscr.2013.02.017.

48. Yamanari MGI, Mansur MCD, et al. Bullet embolism of pulmonary artery: a case report. Radiol Bras 2014 Mar-Apr;47(2):128-130. DOI: 10.1590/S0100-39842014000200018.

49. Doud AN, Hines MH, et al. Management of Venous Bullet Embolus in a Child. Am Surg 2014 Sep;80(9):832-833.

50. Lu K, Gandhi S, et al. Approach to Management of Intravascular Missile Emboli: Review of the Literature and Case Report. West J Emerg Med 2015;16(4):489-496. DOI: 10.5811/westjem.2015.5.25553.

51. Duke E, Peterson AA, et al. Migrating bullet: a case of a bullet embolism to the pulmonary artery with secondary pulmonary infarction after gunshot wound to the left globe. Emerg Trauma Shock 2014 Jan;7(1):38-40. DOI: 10.4103/0974-2700.125638.

52. Echeverria A, Feliciano DV, et al. Pulmonary artery bullet embolism necessitating operative removal. Am Surg 2015 Feb;81(2):E80-E81.

53. Pavlek $S$, Alempijevi $D$, et al. Unusual venous bullet embolism e Case report. J Forensic Leg Med 2016;42:33-36. DOI: 10.1016/ j.jflm.2016.05.012.

54. Imbert PY, Goin G, et al. Pulmonary Artery Bullet Embolism following Cardiac Gunshot Wound. Ann Vasc Surg 2016 Oct;36:290. DOI: 10.1016/j.avsg.2016.02.038.

55. Wilkins T, Rosenkranz ER, et al. Venous bullet embolus to the left pulmonary artery. J Card Surg 2016;31:523-525. DOI: 10.1111/jocs. 12786.

56. Stephenson LW, Workman RB, et al. Bullet emboli to the pulmonary artery: a report of 2 patients and review of the literature. Ann Thorac Surg 1976;21:333-336. DOI: 10.1016/S0003-4975(10)64322-6. 